\title{
Speleomycological research in underground Osówka complex in Sowie Mountains (Lower Silesia, Poland)
}

\author{
Wojciech Pusz $^{1 *}$, Rafał Ogórek ${ }^{1}$, Cecylia Uklańska-Pusz ${ }^{2}$, and Paweł Zagożdżon ${ }^{3}$ \\ ${ }^{1}$ Division of Plant Pathology and Mycology, Department of Plant Protection, Wrocław University of Environmental and Life Sciences, Poland \\ ${ }^{2}$ Department of Horticulture, Wrocław University of Environmental and Life Sciences, Poland \\ ${ }^{3}$ Institute of Mining, Division of Applied Geology, Dewatering and Ecology, Wrocław University of Technology, Poland
}

\begin{abstract}
Osówka (Germ. Säuferhöhen), is one of the elements of the unfinished Nazi military complex called "Riese". The total length of corridors of Osówka complex is about 1,700 m and its capacity amounts to $30,000 \mathrm{~m}^{3}$. As described geologically, Osówka is situated within the Sowie Mts. Massif which consists mostly of various gneisses with different structural characteristics, but with a constant mineral composition. The rock-forming minerals are feldspar (oligoclase), quartz, biotite and light micas, accesory minerals are garnet, sillimanite and dysten. Finegrained shallow-sea deposits were probably a protolith of these rocks. The study aimed at first mycological evaluation of the air and the rocks in Osówka adit. The air samples were taken from one location outside the adit and from four locations inside of it. Mycological evaluation of the rocks inside the adit was performed using three different methods. Fifteen taxa of filamentous fungi were isolated from the internal air sampled, and several taxa - from the outside of the adit, whereas only eleven species were isolated from the rocks. Cladosporium spp. were the fungi most frequently isolated from internal atmosphere of the underground Osówka complex, and from the external air. On the other hand, the fungi most frequently isolated from the rocks were Aspergillus niger group (when using swab sampling procedure) and Mucor spp. (from debris and rinse sampling procedure).
\end{abstract}

Keywords: adit; Osówka; fungi; air; rocks

Received 6 August 2013; Revised 3 November 2013; Accepted 14 November 2013

Citation: Pusz W., Ogórek R., Uklańska-Pusz C. and Zagożdżon P., 2014. Speleomycological research in underground Osówka complex in Sowie Mountains (Lower Silesia, Poland). International Journal of Speleology, 43 (1), 27-34. Tampa, FL (USA) ISSN 0392-6672 http://dx.doi.org/10.5038/1827-806X.43.1.3

\section{INTRODUCTION}

In cavern habitats, fungal habitats generally function as parasites or decomposers. Fungi that can be cultured from materials sampled in caves may not grow in the cave environment, but are present regularly or rarely as spores, carried in by water, air currents, animals, and humans (Chelius et al., 2009; Vanderwolf et al., 2013). The cave mycobiota are very important in cave and underground ecology because fungi and bacteria probably constitute the major food source for other organisms (Sustr et al., 2005; Walochnik \& Mulec, 2009; Bastian et al., 2010). Mycobiota can secrete secondary metabolites, they may cause chemical reactions with the substrate and contaminate the substrate by pigments (Gu, 2003; Li et al., 2008) They may, for instance, cause lithogenic processes, inter alia the speleothem deposition or cavern enlargement (Engel et al., 2004; Cañaveras et al., 2006) as well as litholitic processes (Mulec, 2008). Evidence of the microbial activity in a cave are, among others, dots on the cave surfaces, unusual coloration of speleothems, precipitates, corrosion residues, structural changes and the presence of biofilms (Barton, 2006).

Cave mycobiota are sensitive to changes in organic factors from external sources (Chelius et al., 2009). Therefore this kind of investigation in the undergrounds created by humans is particularly important as it allows recognizing factors that could affect other parts of a cave or underground ecosystems. Presence of tourists in caves or undergrounds exerts influence and results in changes to the microclimate, the biogeochemistry and the balance of organic matter. It may thus have a huge impact on the autochthonous microbial communities like fungi. Frequent visits are therefore always undesirable and such ecosystems should be monitored with respect to the microorganisms present 
in all parts of a cave or undergrounds. The identification of reservoirs of potentially pathogenic fungi and the elucidation of the distribution of these communities and their components are important to prevent health problems in tourists (Fernández-Cortés et al., 2011, Saíz-Jiménez, 2012).

In our work we are using, for the first time, the term "speleomycology" as a name for all kinds of investigation which aim at the recognition of cave and undergrounds mycobiota. The study aimed at first mycological evaluation of the air and the rocks in underground Osówka complex in Sowie Mountains (Lower Silesia, Poland).

\section{DESCRIPTION OF THE STUDIED AREA}

"Osówka" (Germ. Säuferhöhen) is one of the elements of the unfinished Nazi military complex called "Riese". This set of (mostly) underground objects was built between 1943-1945 in the Sowie Mts. (Lower Silesia, SW Poland). Its allocation still remains unclear. The German command gave it a code notation "S3" referring to the main headquarters and production centres of special weapons (retaliation weapons "Verweltungswaffen" and so-called wonder-weapons "Wunderwaffen"). Supervision staff of the works were German miners and experts from Italy, Ukraine and the Czech Republic, whereas the main man working power were prisoners of Gross Rosen concentration camp - many thousands of them died during the works (Kosmaty, 2006).

The underground workings were driven with nitroglycerin explosives. Halls were built in several stages. At first two galleries - upper and lower - were shafted separately. The first of these was widened to the final size, an arched ceiling was constructed and the gallery was concreted eventually. Both drifts were linked by number of small auxiliary shafts for material winding. The lower gallery was widened and the rock beam between drifts was removed then. Finally the lower parts of walls of a hall created in this way were protected by concrete support (Kosmaty, 2006).

"Riese" consists of 7 objects; Osówka is one of the largest. The individual objects are large groups of underground workings (adits, tunnels and halls) of a characteristic regular network system and ventilation shafts (Sienicka \& Zagożdżon, 2010).

Total length of corridors of Osówka complex is about $1,700 \mathrm{~m}$ and its capacity amounts to $30,000 \mathrm{~m}^{3}$. Adits and tunnels are $2.5-4.5 \mathrm{~m}$ wide and $2-4.5 \mathrm{~m}$ high. The width of the halls is about 6-7 $\mathrm{m}$ and their height of $8 \mathrm{~m}$, whereas their length reaches $50 \mathrm{~m}$. The elaboration of individual underground workings had stopped at different stages, thus some halls are completed and fully protected by a concrete support, while some of the others are abandoned in the early stages of construction.

Geologically, Osówka is situated within the Sowie Mts. Massif which consists mostly of various gneisses with different structural characteristics, but with fairly a constant mineral composition. The rockforming minerals are feldspar (oligoclase), quartz, biotite and light micas, accesory minerals are garnet, sillimanite and dysten. Fine-grained shallow-sea deposits were probably a protolith of these rocks. They have undergone several stages of tectonic and metamorphic evolution (Kryza, 1981; Żelaźniewicz, 1987). Protolith age is determined as Late Riphean to - perhaps - Middle Cambrian (Gunia, 1985), i.e. about 800 - $520 \mathrm{Ma}$. Metamorphic processes occurred mainly around 384 - 370 Ma (Żelaźniewicz, 2003). In some places high-grade metamorphism caused the rise of secondary, so-called reomorphic magmas. These magmas moved upward and formed granite and pegmatite veins within the gneiss around $380 \mathrm{Ma}$ ago (Marheine et al., 2002; Żelaźniewicz, 1987).

Only silicate rocks occur in Osówka. A gray biotite, medium-blastic gneiss is a predominant type of rock, it makes approximately more than $95 \%$ of the whole rock mass (Fig. 1). Besides, dark fine-blastic or aphanitic gneisses, transition varieties of gneisses and highly shattered migmatitic gneiss, occurring near the larger zones of dislocation, are found. All these rocks are same in mineral composition - they are dominated by feldspar, about $35 \%$ of the rock volume is biotite, and quartz as well as a rare muscovite are found in them. Veins of reomorphic granites occur fairly frequently in this object.

A number of faults of different scale can be observed here. Wide fault zones are filled with clayey fault flour. Secondary mineralization of quartz and iron oxides and hydroxides is spatially connected with some of the faults (Sienicka \& Zagożdżon, 2010).

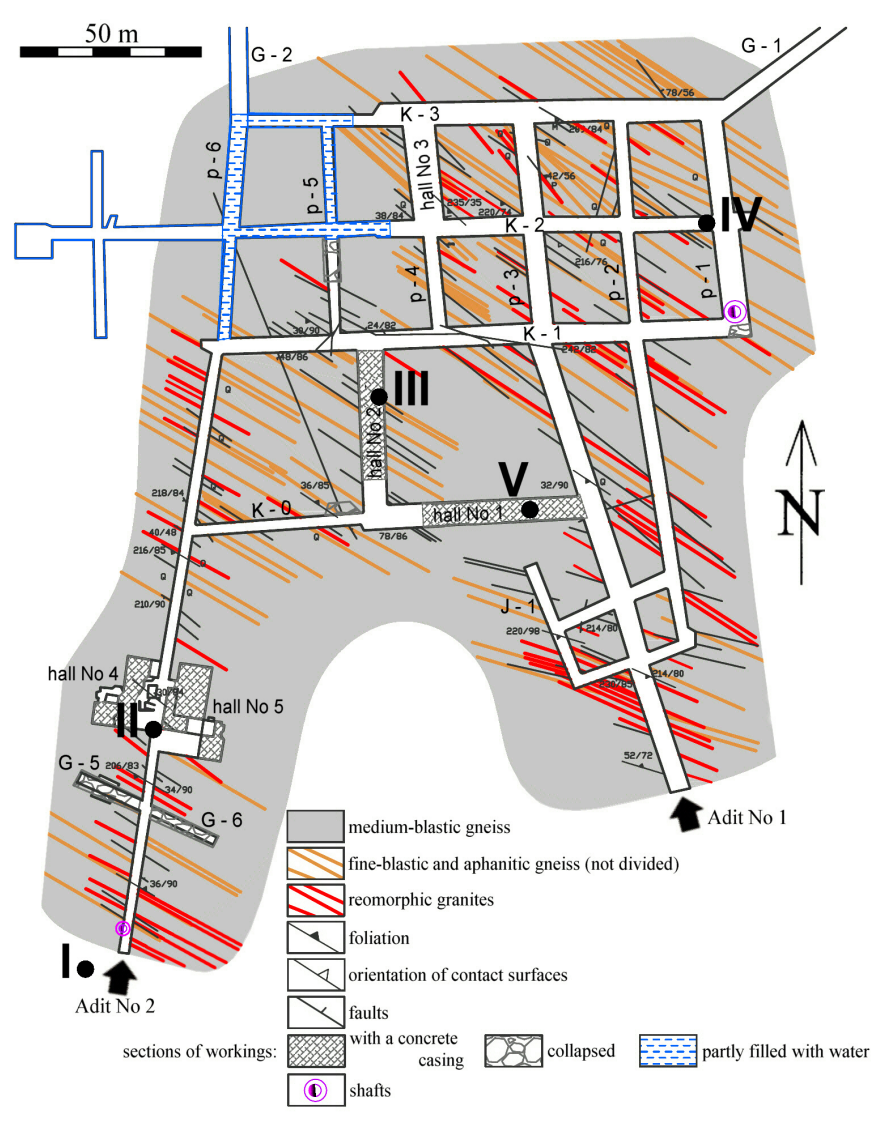

Fig. 1. Geological map of the tourist route in Osówka adit (the occurrences of quartz $(Q)$, pegmatite $(P)$ and mineralization $(M)$ are marked, description of mining workings: $\mathrm{K}$ - halls, G, J, p-drifts) and sampling location: I - near the entrance, II - guard-house, III - hall, IV - ventilation shaft, V - exhibition hall (own study based on Sienicka \& Zagożdżon, 2010). 


\section{MATERIAL AND METHODS}

The samples were taken on the 28th June 2013 from one location outside the adit, near the entrance (air), and from four locations inside (air, rock, debris), that are referred to as: guard-house, hall, ventilation shaft, exhibition hall (see Fig. 1). The air temperature and relative humidity were measured using thermohygrometer LB-522 (LABEL). The carbon dioxide was measured using carbon dioxide meter pSense RH (Gazex). Humidity of rocks was measured with hygrometer Testo 606-1 (Testo) and speed of wind - by Aerometer Testo 410-1 (Testo) - see Table 1.

\section{Mycological evaluation of the air and the rocks} (debris sampling procedure, swab sampling procedure, rinse sampling procedure) were performed according to Ogórek et al. (2013) with minor modification in swab sampling procedure (the samples were taken only from the adit walls and the surface area of $1 \mathrm{~cm}^{2}$ ) and rinse sampling procedure (sample weight was ca. $50 \mathrm{~g}$ ).

\section{Fungal identification}

After incubation $\left(22^{\circ} \mathrm{C}, 2-7\right.$ days, in the darkness $)$, the fungal colonies grown on each one of the Petri dishes of $90 \mathrm{~mm}$ diameter were counted and identified. The specific identfication of the sampled fungi was performed using macro- and microscopic observations, namely the morphology of hyphae, conidia and sporangia, of the colonies that had grown on culture media, according to the commonly accepted methods used in mycological laboratories. The fungi were identified using diagnostic keys (Arx 1974; Ellis, 1971; Raper and Fennell, 1965; Raper and Thom, 1968; Zycha and Siepmann, 1969).

\section{Media}

The following media were used: Potato Dextrose Agar (PDA, Biocorp), Czapek-Dox Agar (1.2\% agar, Biocorp) and Malt Extract Agar (MEA, Biocorp). PDA medium was used for the isolation of fungi from the air and the rocks and for the identification of some species. Czapek-Dox agar medium and MEA medium were used for identification of the Penicillii and Aspergillii.

\section{RESULTS AND DISCUSSION}

The most important factors affecting the survival of fungi in the environment are temperature, humidity (Krzysztofik, 1992) and availability of organic matter. During the presented study, the air and rock humidity inside and outside the adit was conducive for the survival and development of fungi. The air temperature outside was contributory to their development whereas inside the adit - it was not. The content of fungi in the adit is probably determined by other factors such as airflow system in the adit, availability of organic matter and presence of bats or visitors (Hoyos et al., 1998, Gu, 2003; Li et al., 2008). The airflow system in the adit and the speed of wind affect directly the number and species composition of fungi isolated from the air and from the rock. The majority of the fungal colonies forming units were isolated from the locations characterized by the most intensive movement of air. Caves and other subterranean habitats have long been recognized as a nutrient-deficient environment. Energy sources and nutrients can enter caves as atmospheric gases, e.g. carbon dioxide (Mulec, 2008). According to Wels and Uota (1970) some fungal species decrease in abundance when the highest value of carbon dioxide is observed, but in some situations the highest carbon dioxide concentration could stimulate fungi to more intensive growth. It conforms to the results of some other authors (Treseder et al., 2003). In Osówka complex conditions, we have noticed similar $\mathrm{CO}^{2}$ values at all sampling points, thus probably in underground contexts the level of carbon dioxide does not affect the occurrence of fungi (Table 1).

Our research has shown that the most common airborne fungi in the underground are those of the genera of Penicillium, Cladosporium, and Alternaria (Table 2). The work of other researchers surveying caves with respect to fungal spores supports these findings. According to Vanderwolf (2013), the most abundant fungi in caves are Aspergillus, Penicillium, Mucor, Fusarium, Trichoderma, and Cladosporium genera. A Nerja cave (Spain) that had been examined by Docampo (2011), turned out to host several fungal species, with Penicillium and Cladosporium genera being the most numerous. Interestingly, in our investigation near the entrance we sampled mostly Cladosporium spores. Inside the underground mostly Alternaria and Penicillum are present except the exhibition hall, where we found Botrytis cinerea. Our results generally agree with Porca (2011) and Fernández-Cortés (2011). They claimed that the most abundant type of spore in the external environment was Cladosporium, but Aspergillus and Penicillium were the spores most widely represented inside the cave. Hsu and Agoramoorthy (2001), Urzi et al. (2010), Kuzmina et al. (2012) and Mulec et al. (2012) noted that microorganism biodiversity and biomass decreased from the entrance towards the deep zones in caves. We obtained similar results. Near the entrance we numbered $347 \mathrm{CFU}$ per $1 \mathrm{~m}^{3}$ of air. Inside of the underground - approximately 92 to $259 \mathrm{CFU}$ per $1 \mathrm{~m}^{3}$ of air were found, the last value being recorded from ventilation shaft (see Table 2). It is a well-recognized fact that in caves frequently visited by tourists and in those

Table 1. Conditions in Osówka adit.

\begin{tabular}{|c|c|c|c|c|c|c|}
\hline \multirow{2}{*}{$\begin{array}{l}\text { Location of } \\
\text { measurement }\end{array}$} & \multicolumn{2}{|c|}{ Air } & \multirow{2}{*}{$\begin{array}{l}\text { Wind speed } \\
{[\mathrm{m} / \mathrm{s}]}\end{array}$} & \multirow{2}{*}{$\begin{array}{c}\mathrm{CO}^{2} \\
{[\mathrm{ppm}]}\end{array}$} & \multicolumn{2}{|c|}{ Humidity [\%] } \\
\hline & $\begin{array}{c}\text { temperature } \\
{\left[{ }^{\circ} \mathrm{C}\right]}\end{array}$ & $\begin{array}{c}\text { relative air } \\
\text { humidity [\%] }\end{array}$ & & & rocks (wall) & rocks (soil) \\
\hline near the entrance & 23.0 & 78.2 & 1.2 & 382.0 & - & - \\
\hline guard-house & 9.0 & 71.9 & 0.0 & 397.0 & 33.3 & 27.8 \\
\hline hall & 7.9 & 88.9 & 0.0 & 402.0 & 28.9 & 21.7 \\
\hline ventilation shaft & 12.1 & 73.8 & 0.2 & 405.0 & 22.0 & 20.0 \\
\hline exhibition hall & 9.7 & 74.1 & 0.1 & 387.0 & 32.0 & 38.0 \\
\hline
\end{tabular}


Pusz et al.

Table 2. Filamentous fungi isolated from the air inside and outside of Osówka adit.

\begin{tabular}{|c|c|c|c|c|}
\hline \multirow{2}{*}{$\begin{array}{l}\text { Location of } \\
\text { measurement }\end{array}$} & \multirow{2}{*}{ Taxa } & \multicolumn{2}{|c|}{ Air $-\mathrm{CFU} / \mathrm{m}^{3}$} & \multirow{2}{*}{ Species $[\%]$} \\
\hline & & Species & Species & \\
\hline \multirow{11}{*}{ near the entrance } & Alternaria alternata (Fr.) Keissl. & 10 & \multirow{11}{*}{347} & 2.9 \\
\hline & Aspergillus niger group & 2 & & 0.6 \\
\hline & Botrytis cinerea Pers. & 61 & & 17.6 \\
\hline & Cladosporium cladosporioides (Fresen.) G.A. de Vries & 174 & & 50.5 \\
\hline & Cladosporium herbarum (Pers.) Link & 34 & & 9.7 \\
\hline & Fusarium culmorum (W.G. Sm.) Sacc. & 7 & & 2.0 \\
\hline & Mucor spp. & 37 & & 10.8 \\
\hline & Penicillium chrysogenum Thom & 3 & & 0.9 \\
\hline & Penicillium expansum Link & 4 & & 1.2 \\
\hline & Sclerotinia sclerotiorum (Lib.) de Bary & 7 & & 1.9 \\
\hline & Sordaria fimicola (Roberge ex Desm.) Ces. \& De Not. & 7 & & 1.9 \\
\hline \multirow{8}{*}{ guard-house } & Alternaria alternata (Fr.) Keissl. & 60 & \multirow{8}{*}{115} & 52.4 \\
\hline & Aspergillus niger group & 4 & & 3.1 \\
\hline & Cladosporium cladosporioides (Fresen.) G.A. de Vries & 13 & & 10.9 \\
\hline & Mucor spp. & 1 & & 0.9 \\
\hline & Penicillium chrysogenum Thom & 13 & & 10.9 \\
\hline & Penicillium citrinum Thom & 3 & & 2.2 \\
\hline & Penicillium diversum Raper \& Fennel & 20 & & 17.5 \\
\hline & Penicillium expansum Link & 3 & & 2.2 \\
\hline \multirow{6}{*}{ hall } & Cladosporium cladosporioides (Fresen.) G.A. de Vries & 27 & \multirow{6}{*}{92} & 29.0 \\
\hline & Cladosporium herbarum (Pers.) Link & 2 & & 1.6 \\
\hline & Fusarium poae (Peck) Wollenw. & 5 & & 5.5 \\
\hline & Mucor spp. & 10 & & 10.9 \\
\hline & Penicillium citrinum Thom & 15 & & 16.4 \\
\hline & Penicillium expansum Link & 34 & & 36.6 \\
\hline \multirow{12}{*}{ ventilation shaft } & Alternaria alternata (Fr.) Keissl. & 24 & \multirow{12}{*}{259} & 9.1 \\
\hline & Aspergillus niger group & 5 & & 1.9 \\
\hline & Botrytis cinerea Pers. & 31 & & 12.0 \\
\hline & Cladosporium cladosporioides (Fresen.) G.A. de Vries & 53 & & 20.3 \\
\hline & Cladosporium herbarum (Pers.) Link & 10 & & 3.9 \\
\hline & Fusarium oxysporum Schltdl. & 20 & & 7.7 \\
\hline & Mucor spp. & 10 & & 3.9 \\
\hline & Penicillium chrysogenum Thom & 39 & & 14.9 \\
\hline & Penicillium expansum Link & 24 & & 9.1 \\
\hline & Rhizopus spp. & 5 & & 1.9 \\
\hline & Sclerotinia sclerotiorum (Lib.) de Bary & 20 & & 7.7 \\
\hline & Trichoderma harzianum Rifai & 20 & & 7.7 \\
\hline \multirow{5}{*}{ exhibition hall } & Alternaria alternata (Fr.) Keissl. & 5 & \multirow{5}{*}{110} & 4.5 \\
\hline & Botrytis cinerea Pers. & 50 & & 45.5 \\
\hline & Cladosporium cladosporioides (Fresen.) G.A. de Vries & 10 & & 9.1 \\
\hline & Mucor spp. & 15 & & 13.6 \\
\hline & Rhizopus spp. & 30 & & 27.3 \\
\hline
\end{tabular}

hosting bat colonies the concentration of fungal spores in the air has been found higher (Martini, 1963; Shapiro \& Pringle 2010; Porca et al., 2011; Ogórek et al., 2013). The latter is not fully consistent with our results, which show that in the underground of Osowka, although massively attended by tourists and inhabited by bats, the concentration of airborne fungal spores is not high. In our view the effective ventilation system and conditions otherwise unfavourable for the development of fungi are responsible for the difference. The high concentration of airborne fungal spores outside of the adit and in the ventilation shaft was most likely caused by its location, because the surroundings of the adit is mainly covered by spruce monocultures and grasses. Abundant vegetation provides good conditions for development of fungi. Furthermore, studies were carried out in the middle of summer (28th June), in the period of intensive plant growth. This period is particularly conducive for the fungi development.

The most frequently isolated fungi from granite in Osówka complex were Mucor spp. and Aspergillus spp. (Tables 3-5). It is in accordance with work of other authors, who report that most abundant fungal genera isolated from rocks, and from granite in particular, were fungi from the order Mucorales, and Penicillium, Phoma, Auerobasidium, and Trichoderma (Hirsch et al., 1995; Burford et al., 2003a, b; Brunner et al., 2011). However, Ogórek et al. (2013) have reported that most isolated fungus from the rocks of Niedźwiedzia Cave in Kletno is Rhizopus stolonifer.

Seventeen taxa of filamentous fungi were isolated from air (inside and outside) and only eleven from 
Table 3. Filamentous fungi isolated from the rocks soil of Osówka adit (debris sampling procedure).

\begin{tabular}{|c|c|c|c|c|}
\hline $\begin{array}{l}\text { Location of } \\
\text { measurement }\end{array}$ & Taxa & CFU / 25 rocks & Total CFU / 25 rocks & [\%] \\
\hline \multirow{6}{*}{ guard-house } & Mucor spp. & 16.7 & \multirow{6}{*}{32.6} & 51.2 \\
\hline & Penicillium chrysogenum Thom & 8.3 & & 25.5 \\
\hline & Penicillium diversum Raper \& Fennel & 1.2 & & 3.6 \\
\hline & Penicillium expansum Link & 3.0 & & 9.0 \\
\hline & Rhizopus spp. & 0.8 & & 2.3 \\
\hline & Sarocladium strictum (W. Gams) Summerbell & 2.8 & & 8.4 \\
\hline \multirow{4}{*}{ hall } & Aspergillus niger group & 2.8 & \multirow{4}{*}{37.7} & 7.3 \\
\hline & Mucor spp. & 17.2 & & 45.6 \\
\hline & Penicillium chrysogenum Thom & 16.7 & & 44.3 \\
\hline & Penicillium diversum Raper \& Fennel & 1.1 & & 2.9 \\
\hline \multirow{6}{*}{ ventilation shaft } & Aspergillus niger group & 5.6 & \multirow{6}{*}{42.4} & 13.2 \\
\hline & Mucor spp. & 20.3 & & 48.0 \\
\hline & Penicillium chrysogenum Thom & 8.3 & & 19.7 \\
\hline & Penicillium diversum Raper \& Fennel & 0.8 & & 18 \\
\hline & Penicillium expansum Link & 2.7 & & 6.4 \\
\hline & Rhizopus spp & 4.7 & & 11.1 \\
\hline \multirow{4}{*}{ exhibition hall } & Aspergillus niger group & 2.4 & \multirow{4}{*}{29.4} & 5.7 \\
\hline & Mucor spp. & 17.2 & & 40.6 \\
\hline & Penicillium chrysogenum Thom & 8.7 & & 20.5 \\
\hline & Penicillium diversum Raper \& Fennel & 1.1 & & 2.6 \\
\hline
\end{tabular}

Table 4. Filamentous fungi isolated from the rocks soil of Osówka adit (swab sampling procedure).

\begin{tabular}{|c|c|c|c|c|}
\hline $\begin{array}{l}\text { Location of } \\
\text { measurement }\end{array}$ & Taxa & $\begin{array}{c}\mathrm{CFU} / 1 \mathrm{~cm}^{2} \text { rock } \\
\text { surface }\end{array}$ & $\begin{array}{c}\text { Total CFU / } \\
1 \mathrm{~cm}^{2} \text { rock surface }\end{array}$ & [\%] \\
\hline \multirow{5}{*}{ guard-house } & Aspergillus niger group & 11.2 & \multirow{5}{*}{32.6} & 34.4 \\
\hline & Mucor spp. & 5.2 & & 16.0 \\
\hline & Penicillium chrysogenum Thom & 5.1 & & 15.7 \\
\hline & Penicillium expansum Link & 1.2 & & 3.7 \\
\hline & Rhizopus spp. & 9.8 & & 30.2 \\
\hline \multirow{4}{*}{ hall } & Aspergillus niger group & 10.9 & \multirow{4}{*}{34,7} & 31.4 \\
\hline & Mucor spp & 12.1 & & 34.9 \\
\hline & Penicillium chrysogenum Thom & 1.0 & & 2.9 \\
\hline & Rhizopus spp. & 10.7 & & 30.8 \\
\hline \multirow{4}{*}{ ventilation shaft } & Aspergillus niger group & 39.8 & \multirow{4}{*}{54.9} & 72.5 \\
\hline & Mucor spp & 13.6 & & 24.8 \\
\hline & Penicillium chrysogenum Thom & 1.0 & & 1.9 \\
\hline & Rhizopus spp & 0.4 & & 0.8 \\
\hline \multirow{3}{*}{ exhibition hall } & Aspergillus niger group & 10.4 & \multirow{3}{*}{24.0} & 43.3 \\
\hline & Mucor spp & 10.2 & & 42.5 \\
\hline & Rhizopus spp. & 3.4 & & 14.2 \\
\hline
\end{tabular}

the rock (Tables 2-5). Microbiological evaluation of the rocks was performed using three methods and we obtained different results using each method. Most of the species of fungi were isolated using rinse sampling procedure and the least species by swab sampling procedure. Cladosporium spp., namely $\mathrm{C}$. cladosporioides and $\mathrm{C}$. herbarum, were the fungi most frequently isolated from the internal atmosphere of the underground Osówka complex and from the air outside. Conversely, those most frequently isolated from the rocks were Aspergillus niger group when using swab sampling procedure and Mucor spp. when using debris and rinse sampling procedure. Ogórek et al. (2013) reported that differences in the number of fungi species on the rock substrate may be caused by imprecision of the testing methods used or by the difference in the samples collected in each location. Therefore, the microbiological evaluation of the rocks should be accomplished using several methods.
Cladosporium spp. are common in many parts of the world, as they are cosmopolitan organisms. Their spores can be found in air, soil and water (Domsch et al., 1980; Ogórek et al., 2012). These fungi are active at low temperatures and in high air humidity (Kwon et al., 2001). Studies of atmospheric air of various regions of Europe show that the spores of Cladosporium spp. dominate in $80 \%$ of all the caught spores (D'Amato \& Spieksma, 1995) and the peak season is in the summer time (Lipiec, 2000). Some species are pathogenic to various crops, causing economically important plant diseases, while others are important only endemically. Fungi commonly occur as saprotrophs on crop remnants and plant remnants (Mazurkiewicz-Zapłowicz \& Grajewski, 2010). Cladosporium spp. can cause allergic reaction in humans, opportunistic infections, and that is mainly related to patients with their immune system compromised, such as patients with haematological 
Pusz et al.

Table 5. Filamentous fungi isolated from the rocks wall of Osówka adit (rinse sampling procedure).

\begin{tabular}{|c|c|c|c|c|}
\hline $\begin{array}{c}\text { Location of } \\
\text { measurement }\end{array}$ & Taxa & $\begin{array}{l}\mathrm{CFU} / 50 \mathrm{~g} \\
\text { rock }\end{array}$ & $\begin{array}{l}\text { Total CFU / } \\
50 \text { g rock }\end{array}$ & {$[\%]$} \\
\hline \multirow{4}{*}{ guard-house } & Mucor spp. & 60.4 & \multirow{4}{*}{120.9} & 50.0 \\
\hline & Penicillium chrysogenum Thom & 19.9 & & 16.5 \\
\hline & Rhizopus spp. & 20.5 & & 17.0 \\
\hline & Sarocladium strictum (W. Gams) Summerbell & 20.1 & & 16.6 \\
\hline \multirow{5}{*}{ hall } & Cladosporium cladosporioides (Fresen.) G.A. de Vries & 21.4 & \multirow{5}{*}{164.8} & 13.0 \\
\hline & Fusarium culmorum (W.G. Sm.) Sacc. & 9.8 & & 5.9 \\
\hline & Mucor spp. & 100.6 & & 61.0 \\
\hline & Penicillium chrysogenum Thom & 12.3 & & 7.5 \\
\hline & Rhizopus spp. & 20.7 & & 12.6 \\
\hline \multirow{6}{*}{ ventilation shaft } & Aspergillus niger group & 59.5 & \multirow{6}{*}{205.1} & 29.0 \\
\hline & Cladosporium cladosporioides (Fresen.) G.A. de Vries & 5.7 & & 2.8 \\
\hline & Mucor spp. & 90.3 & & 44.0 \\
\hline & Penicillium chrysogenum Thom & 35.0 & & 17.1 \\
\hline & Penicillium citrinum Thom & 10.0 & & 4.9 \\
\hline & Sclerotinia sclerotiorum (Lib.) de Bary & 4.6 & & 2.2 \\
\hline \multirow{3}{*}{ exhibition hall } & Aspergillus niger group & 33.5 & \multirow{3}{*}{83.4} & 40.2 \\
\hline & Mucor spp. & 45.3 & & 54.3 \\
\hline & Rhizopus spp. & 17.9 & & 21.5 \\
\hline
\end{tabular}

diseases or those showing AIDS (Plomer-Niezgoda et al., 1998).

Mucor spp. have a cosmopolitan distribution and can be isolated from almost any organic material that is in contact with air (Hesseltine, 1955). They are mostly known as spoilage organisms and only one species ( $M$. piriformis) has been reported as a pathogen on stone and pome fruit (Michailides \& Spotts, 1988). $M$. circinelloides can cause cutaneous zygomycosis in humans (Chandra \& Woodgyer, 2002).

Aspergillus species are ubiquitous environmental molds that grow on organic matter and aerosolize conidia (Hope et al., 2005). These fungi are able to grow in the wide temperature range of $6-47^{\circ} \mathrm{C}$ (optimum at $35-37^{\circ} \mathrm{C}$ ) and are able to grow over an extremely wide $\mathrm{pH}$ range $1.4-9.8$. These abilities and the profuse production of conidiospores, which are distributed via the air, secure the ubiquitous occurrence of the species, with a higher frequency in warm and humid places (Rippel-Baldes, 1955). Aspergillus spp. are fermentative microorganisms and they can excrete many organic acids into the environment, including the acids which may cause biodeterioration of natural stones, as well as brick, concrete or mortars (Gu et al., 1998; Cwalina, 2008). In humans they may cause infections, e.g. aspergillosis of the lungs, sinuses, cornea, orbit, skin, nails, and of ear canal, or act as allergens (Adamski et al., 2008).

\section{CONCLUSIONS}

Mycobiota of underground habitats created by humans are generally similar to those found in natural caves. Species that occur in sites of this kind are dependent, in their propagation, on tourists, presence of bats and another animals and ventilation. These "factors" are thus the main source of fungal spores present inside shafts and adits. Fungal spore concentration and number of species in majority of the adits of Osówka complex does not present a health risk to the tourists attending the site. Yet, as it is enhanced in some portions of the adits, it may constitute a problem for historical objects like mining trolleys or uniforms. Therefore it seems that speleomycological research and monitoring are important for underground ecosystems and for protection of historical memorabilia.

\section{ACKNOWLEDGEMENTS}

We would like to thank the Management Staff of the Osówka complex and Mr. Zdzisław Łazanowski for their help in the study.

\section{REFERENCES}

Adamski Z., Henke K., Zawirska A. \& Kubisiak-Rzepczyk H., 2008 - Grzybice narzadowe. In: Baran E. (Eds.), Mikologia - co nowego? Wrocław: Cornetis: 189-202 p.

Arx J.A., 1974 - The genera of fungi sporulating in pure culture. J. Cramer, Berlin, 315 p.

Barton H.A., 2006 - Introduction to cave microbiology: a review for the non-specialists. Journal of Cave and Karst Studies, 68: 43-64.

Bastian F., Jurado V., Novakova A., Alabouvette C. \& Saíz-Jiménez C., 2010 - The microbiology of Lascaux Cave. Microbiology, 156: 644-652. http://dx.doi.org/10.1099/mic.0.036160-0

Brunner I., Plotze M., Rieder S., Zumsteg A., Furrer G. \& Frey B., 2011 - Pioneering fungi from the Damma glacier forefield in the Swiss Alps can promote granite weathering. Geobiology, 9: 266-279. http://dx.doi.org/10.1111/j.1472-4669.2011.00274.x

Burford E.P., Fomina M \& Gadd G.M., 2003b - Fungal involvement in bioweathering and biotransformation of rocks and minerals. Mineralogical Magazine, 67: 11271155. http://dx.doi.org/10.1180/0026461036760154 Burford E.P., Kierans M.,\&Gadd G.M., 2003a-Geomycology: fungi in mineral substrata. Mycologist, 17 (3): 98-107. http://dx.doi.org/10.1017/S0269915X03003112

Cañaveras J.C., Cuezva S., Sánchez-Moral S., Lario J., Laíz L., Gonzáles J.M. \& Saíz-Jiménez C., 2006 - On the origin of fiber calcite crystals in moonmilk deposits. Naturwissenschaften, 93: 27-32.

http://dx.doi.org/10.1007/s00114-005-0052-3 
Chandra S. \& Woodgyer A. 2002 - Primary cutaneous zygomycosis due to Mucor circinelloides. Australasian Journal of Dermatology, 43: 39-42.

http://dx.doi.org/10.1046/j.1440-0960.2002.00550.x

Chelius M.K, Beresford G., Horton H., Quirk M., Selby G., Simpson R.T., Horrocks R. \& Moore J.C., 2009 - Impacts of alterations of organic inputs on the bacterial community within the sediments of Wind Cave, South Dakota, USA. International Journal of Speleology, 38: 1-10.

http://dx.doi.org/10.5038/1827-806X.38.1.1

Cwalina B., 2008 - Biodeterioration of concrete. Architecture Civil Engineering Environment, 4: 133-140.

D'Amato G. \& Spieksma FThM, 1995 - Aerobiologic and clinical aspects of mould allergy in Europe. Allergy, 50: $870-877$.

http://dx.doi.org/10.1111/j.1398-9995.1995.tb02492.x

Docampo S., Trigo M.M., Recio M., Melgar M., GarcíaSánchez J. \& Cabezudo B., 2011 - Fungal spore content of the atmosphere of the Cave of Nerja (southern Spain): diversity and origin. Science of the Total Environment, 409: 835-843.

http://dx.doi.org/10.1016/j.scitotenv.2010.10.048

Domsch K.H., Games W. \& Anderson T.H., 1980 Compendium of soil fungi. Academic Press, London.

Ellis M.B., 1971 - Dematiaceous Hyphomycetes. Commonwealth Mycological Institute, Kew, Surrey, 30 p.

Engel A.S., Stern L.A. \& Bennett P.C., 2004 - Microbial contributions to cave formation: New insights into sulfuric acid speleogenesis. Geology, 32: 369-372. http://dx.doi.org/10.1130/G20288.1

Fernández-Cortés A., Cuezva S., Sánchez-Moral S., Cañaveras J.C., Porca E., Jurado V., Martín-Sánchez P.M. \& Saíz-Jiménez C., 2011 - Detection of human-induced environmental disturbances in a show cave. Environmental Science and Pollution Research, 18: 1037-1045. http://dx.doi.org/10.1007/s11356-011-0513-5

Gu J.D., 2003 - Microbiological deterioration and degradation of synthetic polymeric materials: recent research advances. International Biodeterioration and Biodegradation, 52: 69-91.

http://dx.doi.org/10.1016/S0964-8305(02)00177-4

Gu, J.D., Ford, T.E., Berke, N.S. \& Mitchell, R., 1998 - Biodeterioration of concrete by the fungus Fusarium. International Biodeterioration and Biodegradation, 41: 101-109.

http://dx.doi.org/10.1016/S0964-8305(98)00034-1

Gunia T., 1985 - Geological position of the Sowie Góry block and its influence on the paleogeography of the Paleozoic of Central Sudetes. Geology Sudetów, 20: 83-119.

Hesseltine C.W., 1955 - Genera of Mucorales with notes on their synonomy. Mycologia, 47: 344-363. http://dx.doi.org/10.2307/3755457

Hirsch P., Eckhardt F. E. W. \& Palmer Jr. R. J., 1995 Fungi active in weathering of rock and stone monuments. Canadian Journal of Botany, 73: 1384-1390. http://dx.doi.org/10.1139/b95-401

Hope W.W., Walsh T.J. \& Denning D.W. 2005 Laboratory diagnosis of invasive aspergillosis. The Lancet Infectious Diseases, 10: 609-622. http://dx.doi.org/10.1016/S1473-3099(05)70238-3

Hoyos M., Soler V., Canãveras J.C., Sánchez-Moral S. \& Sanz-Rubio E., 1998 - Microclimatic characterization of a karstic cave: human impact on microenvironmental parameters of a prehistoric rock art cave (Cándamo Cave, northern Spain). Environmental Geology, 33: 231-242. http://dx.doi.org/10.1007/s002540050242

Hsu M.J. \& Agoramoorthy G., 2001 - Occurrence and diversity of thermophilous soil microfungi in forest and cave ecosystems of Taiwan. Fungal Diversity, 7: 27-33. http://dx.doi.org/10.1134/S0026261712010109
Kosmaty J., 2006 - Mining activities in Sowie Mountains within a framework of "Riese"program during Second World War. Scientific Papers of the Institute of Mining of the Wroclaw University of Technology 117, Studies and Research, 32: 145-161.

Kryza R., 1981 - Migmatization in gneisses of northern part of the Sowie Góry, Sudetes. Geology Sudetów, XVI (1): 7-100.

Krzysztofik B., 1992 - Mikrobiologia powietrza. Wydawnictwo Politechniki Warszawskiej, Warszawa, 198 p.

Kuzmina L.Y., Galimzianova N.F., Abdullin S.R \& Ryabova A.S., 2012 - Microbiota of the Kinderlinskaya Cave (South Urals, Russia). Microbiology, 81 (2): 251258. http://dx.doi.org/10.1134/S0026261712010109

Kwon J.H, Kang S.W., Kim J.S. \& Park C.S., 2001 - Scab of tea (Thea sinensis) caused by Cladosporium herbarum in Korea. The Plant Pathology Journal, 17: 350-353.

Li X.S., Arai H., Shimoda I., Kuraishi H. \& Katayama Y., 2008 - Enumeration of sulfuroxidizing microorganisms on deteriorating stone of the Angkor monuments, Cambodia. Microbes and Environments, 23: 293-298. http://dx.doi.org/10.1264/jsme2.ME08521

Lipiec A., 2000 - Mould hypersensitivity in allergic rhinitis patients. International Review of Allergology and Clinical Immunology, 6: 2-3.

Marheine D., Kachlik V., Maluski H., Patočka F. \& Żelaźniewicz A., 2002 - The Ar-Ar ages from the West Sudetes (NE Bohemian Massif): constraints on the Variscan polyphase tectonothermaldevelopment. In: Winchester J.A., Pharaoh T.C., Verniers J. (Eds.) Paleozoic amalgamation of Central Europe. Geological Society Publications, 201 p.

Martini A., 1963 - Yeasts in cavern environments. Archiv fur Mikrobiologie, 45: 111-114. http://dx.doi.org/10.1007/BF00408431

Mazurkiewicz-Zapłowicz K. \& Grajewski J., 2010 Grzyby fyllosfery Acorus calamus L. - cennej rośliny leczniczej. Progress in Plant Protection, 50: 236-239.

Michailides T.J. \& Spotts R.A. 1988 - Germination of zygospores of Mucor piriformis (on the life history of Mucor piriformis). Mycologia, 80: 837-844. http:/ / dx.doi.org/10.2307/3807563

Mulec J., 2008 - Microorganisms in hypogen: examples from Slovenian karst caves. ACTA Carsologica, 153-160.

Mulec J., Vaupotic J. \& Walochnik J., 2012 - Prokaryotic and eukaryotic airborne microorganisms as tracers of microclimatic changes in the underground (Postojna Cave, Slovenia). Environmental Microbiology, 64: 654-667.

Ogórek R., Lejman A. \& Matkowski K. 2013 - Fungi isolated from Niedźwiedzia Cave in Kletno (Lower Silesia, Poland). International Journal of Speleology, 42: 161166. http://dx.doi.org/10.5038/1827-806X.42.2.9

Ogórek R., Lejman A., Pusz W., Miłuch A. \& Miodyńska P., 2012 - Characteristics and taxonomy of Cladosporium fungi. Mikologia Lekarska, 19: 80-85.

Plomer-Niezgoda E., Baran E., Maj J., Czarnecka A. \& Hryncewicz-Gwóźdź, A., 1998 - Pathogenicity of fungi from the genus of Alternaria, Cladosporium and Chrysosporium. Mikologia Lekarska, 5: 187-190.

Porca E., Jurado V., Martín-Sánchez P.M., Hermosin B., Bastian F., Alabouvette C. \& Saíz-Jiménez C., 2011 Aerobiology: an ecological indicator for early detection and control of fungal outbreaks in caves. Ecological Indicators, 11: 1594-1598. http://dx.doi.org/10.1016/j.ecolind.2011.04.003

Raper K.B. \& Fennel D.I., 1965 - The genus Aspergillus. Willims and Wilkins Company, Baltimore, 686 p.

Raper K.B. \& Thom C., 1968 - A manual of the Penicillia. Hafner Publishing Company, New York, 875 p.

Rippel-Baldes A. 1955 - Grundzüge der Mikrobiologie, 3rd. Springer, Berlin Heidelberg, New York, 418 p. http://dx.doi.org/10.1007/978-3-662-01454-7 
Saíz-Jiménez C. 2012 - Microbiological and environmental issues in show caves. World Journal of Microbiology and Biotechnology, 28 (7): 2453-2464.

http://dx.doi.org/10.1007/s11274-012-1070-x

Shapiro J. \& Pringle A., 2010 - Anthropogenic influences on the diversity of fungi isolated from caves in Kentucky and Tennessee. American Midland Naturalist, 163 (1): 7686. http://dx.doi.org/10.1674/0003-0031-163.1.76

Sienicka K. \& Zagożdżon P., 2010 - A detailed geological map of Osówka Object ("Riese” Complex) (in Polish). In: Zagożdżona P., Madziarza M., (Eds.), - Dzieje górnictwa - element europejskiego dziedzictwa kultury, 3 ed., Wrocław, 415-430.

Sustr V., Elhottova D., Kristufek V., Lukesova A. \& Novakova A., Tajovsky K., Triska J., 2005 - Ecophysiology of the cave isopod Mesoniscus graniger (Frivaldszky 1865) (Crustacea: Isopoda). European Journal of Soil Biology, 41: 69-75. http://dx.doi.org/10.1016/j.ejsobi.2005.09.008

Treseder K., Egerton-Warburton L.M., Allen M.F., Cheng Y. \& Oechel W.C., 2003 - Alteration of soil carbon pools and communities of mycorrhizal fungi in chaparral exposed to elevated carbon dioxide. Ecosystems, 6 (8): 786-796. http://dx.doi.org/10.1007/s10021-003-0182-4
Vanderwolf K.J., Malloch D., McAlpine D.F. \& Forbes G.J. 2013 - A world review of fungi, yeasts, and slime molds in caves. International Journal of Speleology, 42 (1): 77-96. http://dx.doi.org/10.5038/1827-806X.42.1.9

Walochnik J. \& Mulec J. 2009 - Free-living amoebae in carbonate precipitating microhabitats of karst caves and a new vahlkampfiid amoeba, Allovahlkampfia spelaea gen. nov., sp. nov. Acta Protozoologica, 48: 25-33.

Wells J.M. \& Uota M. 1970 - Germination and growth of five fungi in low-oxygen and high-carbon dioxide atmospheres. Phytopathology, 60 (1): 50-53. http://dx.doi.org/10.1094/Phyto-60-50

Żelaźniewicz A., 1987 - Tectonic and metamorphic evolution of the Sowie Góry, Sudetes Mts., SW Poland. Rocznik PTG, 57 (3-4): 03-348.

Żelaźniewicz A., 2003 - Developments in the geology of the crystalline basement of the West Sudetes in 19902003. In: Ciężkowski W., Wojewoda J., \& Żelaźniewicz A. (Eds.) Sudety zachodnie: od wendu do czwartorzędu. Wrocław: WIND: 7-15.

Zycha H. \& Siepmann R., 1969 - Mucorales. J. Cramer, Berlin, 355 p. 